\title{
First Report of Tomato chlorotic spot virus in Sweet Basil (Ocimum basilicum) and Purslane (Portulaca oleracea) in Florida
}

Richard N. Raid, EREC, University of Florida, Belle Glade 33430; Joel R. Allingham, Agricare, Palm City, FL 34990; Joseph E. Funderburk, NFREC, University of Florida, Quincy 67891; Thomas Skarlinsky, USDA-APHIS-PPQ, Miami, FL 33266; Samuel F. Hutton, GCREC, University of Florida, Wimauma 33598; William W. Turechek and Scott Adkins, USDA-ARS, Fort Pierce, FL 34945

Accepted for publication 17 May 2017.

Since 2012, the tospovirus Tomato chlorotic spot virus (TCSV) has emerged as a pathogen of vegetables, ornamentals, and weeds in Florida and the Caribbean (Estévez de Jensen et al. 2017; Webster et al. 2015). In South Florida, TCSV has been detected in tomato (Solanum lycopersicum), bell pepper (Capsicum annuum), annual vinca (Catharanthus roseus), waxflower (Hoya wayetii), and American black nightshade (Solanum americanum) (Badillo-Vargas et al. 2015; Baker and Adkins 2015; Warfield et al. 2015; Webster et al. 2015). Like other tospoviruses, TCSV is transmitted by several species of thrips (order Thysanoptera, family Thripidae) (Webster et al. 2015).

In October 2016, typical tospovirus symptoms that consisted of chlorotic and necrotic ringspots and oak leaf patterns were observed on older leaves of sweet basil (Ocimum basilicum, family Lamiaceae; Fig. 1A, B) in eastern Palm Beach County, FL. Disease incidence within the $\sim 0.5$-ha planting was $>50 \%$. Symptomatic field plants were transplanted to greenhouses in Belle Glade and Fort Pierce, where subsequent new foliar growth was symptom-free (Fig. 1C) while original symptomatic leaves senesced (Fig. 1D). In December 2016, chlorotic and necrotic ring and spot symptoms were observed on $\sim 30 \%$ of bell pepper plants in several fields in eastern Palm Beach County. Purslane (Portulaca oleracea, family Portulacaceae) was the predominant weed observed in these fields (Fig. 2A) and exhibited discolored and chlorotic rings or spots (Fig. 2B to D).

Samples of sweet basil, bell pepper, and purslane tested positive with Tomato spotted wilt virus (TSWV) lateral flow immunoassay reagents (Agdia, Elkhart, IN). Previous research has shown that a positive result with this assay indicates the presence of one or more tospoviruses since these reagents react with TSWV and several closely related tospoviruses including TCSV and Groundnut ringspot virus (GRSV) (Adkins et al. 2015). A Nicotiana benthamiana plant was mechanically inoculated with symptomatic sweet basil leaves from several plants using $0.5 \%$ (wt/vol) sodium sulfite. Symptoms typical of tospovirus infection developed $\sim 10$ days postinoculation. Seven additional samples of symptomatic purslane also tested positive with GRSV/TCSV enzyme-linked immunosorbent assay (ELISA) reagents (Agdia, Elkhart, IN).

To identify the specific tospovirus present, one sweet basil plant, the $N$. benthamiana plant inoculated with basil leaves, 11 bell pepper, and 13 purslane samples were further analyzed as follows. Total RNA was extracted from symptomatic leaves of all samples using the RNeasy Plant Mini Kit (Qiagen, Valencia, CA) and tested by RT-PCR

Corresponding author: Scott Adkins; scott.adkins@ars.usda.gov

This article is in the public domain and not copyrightable. It may be freely reprinted with customary crediting of the source. The American Phytopathological Society, 2017. with TCSV-specific RNA-dependent RNA polymerase (L), movement protein $(\mathrm{NSm})$, or nucleocapsid $(\mathrm{N})$ gene primers as previously described (Webster et al. 2015). Amplicons of the expected sizes were obtained with all three TCSV primer sets from all samples. Products
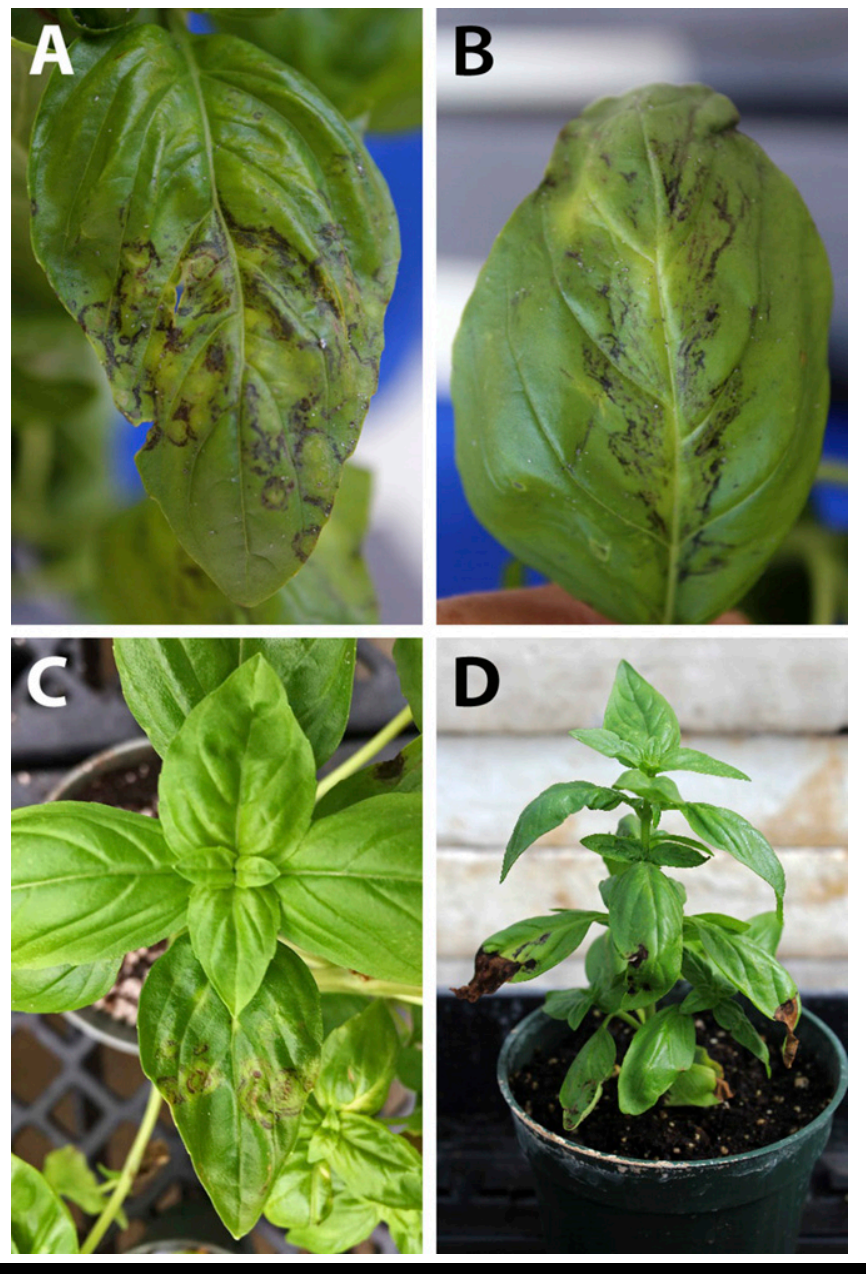

\section{FIGURE 1}

Symptoms of Tomato chlorotic spot virus infection of sweet basil in Florida. Foliar chlorosis and necrosis in ringspots $(\mathbf{A})$ and oak leaf patterns $(\mathbf{B})$ especially apparent in older leaves observed in October 2016. New growth on infected field plants dug and moved to greenhouse was symptom-free (C, note original symptomatic leaf with ringspots at bottom of photograph). Original symptomatic leaves eventually became completely necrotic (D, near bottom of plant) and senesced after $\sim 1$ month. 

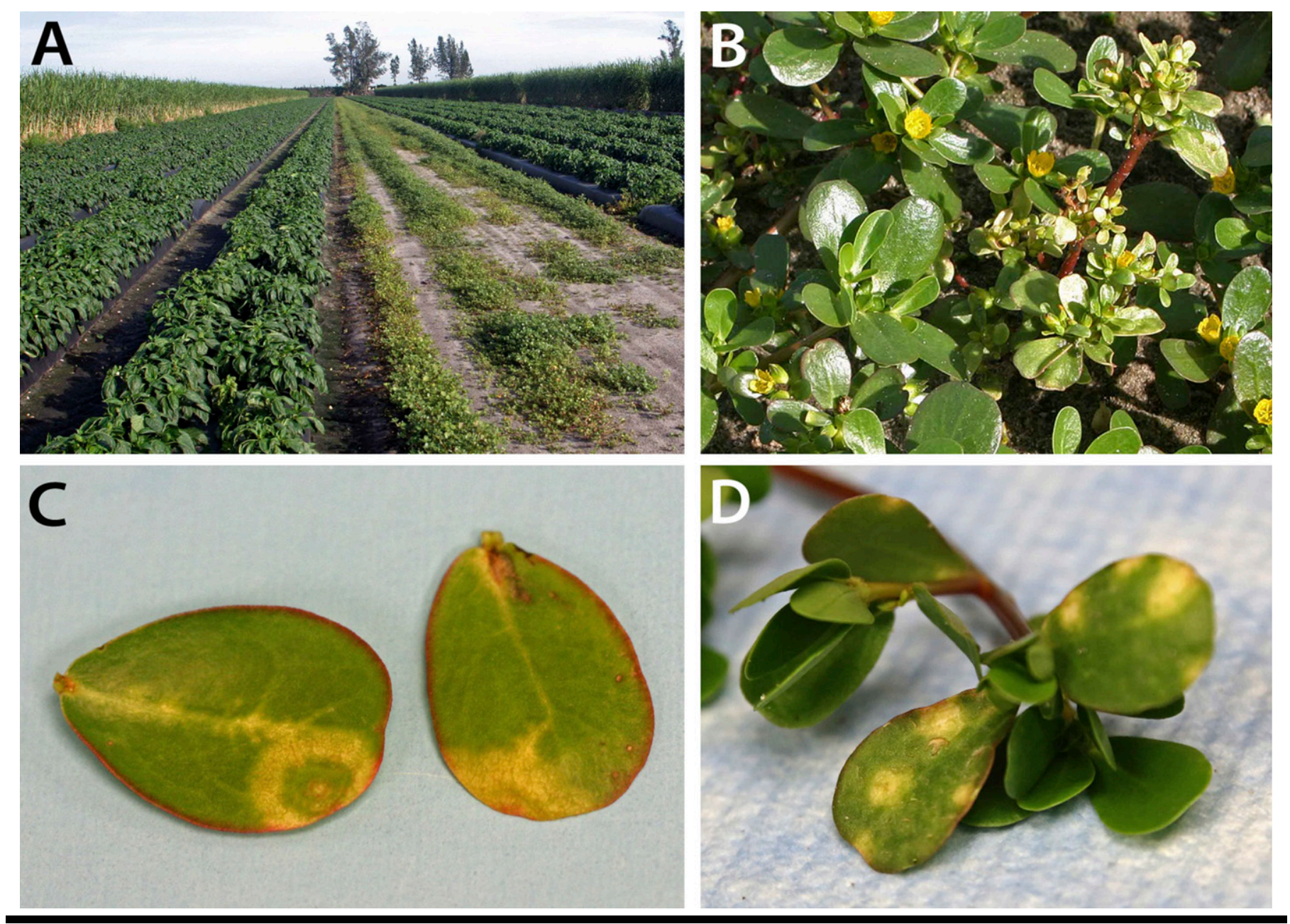

FIGURE 2

Purslane was the predominant weed observed in bell pepper fields in January 2017 (A, note abundance in drive row on right of photograph). Symptoms of Tomato chlorotic spot virus (TCSV) infection were readily apparent on purslane in the field as chlorosis or bleaching of young leaves (B, compare leaves of noninfected plants on left of photograph to those of infected plant on right). Symptoms on individual purslane leaves consisted of diffuse chlorotic rings and spots (C and $\mathbf{D})$.

were not amplified from any sample using primers specific for the N gene of TSWV or GRSV (Webster et al. 2013).

Three TCSV amplicons (L, NSm, and N) from the basil, the $N$. benthamiana, and four purslane samples were gel-purified and cloned (pGEM-T, Promega, Madison, WI). Five clones of each amplicon were sequenced in both directions and consensus sequences were deposited in GenBank (Accession Nos. KY820951 to KY820966). All three genes had 96 to $100 \%$ nucleotide sequence identity with TCSV isolates in GenBank. Corresponding amplicons showed 98 to $100 \%$ nucleotide sequence identity to each other across all plant species in this report.

In December 2016, bell pepper flowers were collected to examine for thrips. Nineteen Frankliniella schultzei adults and 40 Frankliniella spp. larvae were obtained. In January 2017, purslane flowers were also collected and examined for thrips. A single $F$. schultze $i$ adult and eight Frankliniella spp. larvae were obtained. Three of these larvae were placed on microscope slides and identified as $F$. schultzei. This demonstrated $F$. schultzei reproduction on purslane, a key factor in TCSV epidemiology since thrips larvae must acquire tospoviruses for subsequent transmission as adults. F. schultzei is a known TCSV vector and has previously been observed on other TCSVinfected plant species in Florida and Puerto Rico (Estévez de Jensen et al. 2017).
This is the first report of TCSV infection of sweet basil and purslane in Florida. To the best of our knowledge, this is also the first report of TCSV infection of these particular plant species from any location. Symptomless new growth and senescence of symptomatic older leaves of sweet basil suggest that systemic TCSV infection may be rare in this host although additional confirmation is needed. Purslane is now added to the growing list of weed species that serve as reservoirs for TCSV and its thrips vectors in Florida and the Caribbean. We note that selections of purslane are grown as ornamental crops and commonly sold as portulaca. In fact, while this report was in review we detected TCSV-infected portulaca at a nursery in St. Lucie County. Identification of sweet basil, purslane, and portulaca as natural TCSV hosts demonstrates the need for further study of this emerging tospovirus.

\section{Acknowledgments and Disclaimers}

The research in this report was supported, in part, by Florida Specialty Crop Block Grants 22901 and 24049, and USDA-AFRI CAP Grant 201268004-20166. The use of trade, firm, or corporation names in this publication is for the information and convenience of the reader. Such use does not constitute an official endorsement or approval by the United States Department of Agriculture or the Agricultural Research Service of any product or service to the exclusion of others that may be suitable. 


\section{Literature Cited}

Adkins, S., Webster, C. G., Mellinger, H. C., Frantz, G., Turechek, W. W., McAvoy, E., Reitz, S. R., and Funderburk, J. E. 2015. Detection and characterization of tomato viruses: A case study of emerging tospoviruses in Florida. Acta Hortic. 1069:83-85.

Badillo-Vargas, I. E., Roe, N., Funderburk, J. E., and Adkins, S. 2015. First report of Tomato chlorotic spot virus in scarlet eggplant (Solanum aethiopicum) and American black nightshade (Solanum americanum) in the United States. Plant Dis. 99:1450.

Baker, C. A., and Adkins, S. 2015. First report of Tomato chlorotic spot virus in Hoya wayetii and Schlumbergera truncata. Plant Health Prog. 16:29-30.

Estévez de Jensen, C., Badillo-Vargas, I. E., Frantz, G., Mellinger, H. C., Turechek, W. W., Hutton, S. F., Funderburk, J. E., Naidu, R. A., and Adkins, S. 2017. First report of Tomato chlorotic spot virus in non-solanaceous weeds erect spiderling (Boerhavia erecta) and Asian spiderflower (Cleome viscosa), and sweet chili pepper (Capsicum chinense) in Puerto Rico. Plant Health Prog. 18:17-18.

Warfield, C. Y., Clemens, K., and Adkins, S. 2015. First report of Tomato chlorotic spot virus on annual vinca (Catharanthus roseus) in the United States. Plant Dis. 99:895.

Webster, C. G., Estévez de Jensen, C., Rivera-Vargas, L. I., Rodrigues, J. C. V., Mercado, W., Frantz, G., Mellinger, H. C., and Adkins, S. 2013. First report of Tomato chlorotic spot virus in tomato, pepper and jimsonweed in Puerto Rico. Plant Health Prog. doi:10.1094/PHP-2013-081201-BR.

Webster, C. G., Frantz, G., Reitz, S. R., Funderburk, J. E., Mellinger, H. C., McAvoy, E., Turechek, W. W., Marshall, S. H., Tantiwanich, Y., McGrath, M. T., Daughtrey, M. L., and Adkins, S. 2015. Emergence of Groundnut ringspot virus and Tomato chlorotic spot virus in vegetables in Florida and the southeastern United States. Phytopathology 105:388-398. 